\title{
The convergence of the Central American countries to International Accounting Standards
}

\author{
Carlos Araya-Leandro \\ Universidad de Costa Rica (UCR) / Vicerrectoría de Administración \\ San José / Costa Rica \\ María Del Carmen Caba-Pérez \\ Universidad de Almería (UAL) / Facultad de Ciencias Económicas y Empresariales \\ Almería / Spain
}

Antonio M. López-Hernandez

Universidad de Granada (UGR) / Departamento de Economía Financiera y Contabilidad

Granada / Spain

\begin{abstract}
In the last few decades, Central American countries are making a significant effort in order to modernize their governments' legislation both on financial management and systems of financial information. In this sense, these countries aim to enhance the quality of public financial information in order to improve decision-making processes, decrease the level of corruption, and keep citizens informed. In this context, the purpose of this paper is twofold. Firstly, to assess the degree of similarity of the financial information that is being developed by Central American governments with regard to the recommendations set up by Ipsas, and secondly, to analyse the efforts and the strategies that those countries are carrying out in the process of implementing those standards. To determine the differences in the information containing the annual financial statements issued by national public authorities and the recommendations set up by Ipsas we conducted a deductive content analysis. In view of the results we can say that the quality of annual financial statements presented by the countries in Central America, in comparison to the recommendations by the Ipsas concerning Ifac information, is not enough. Hence, in order to operate significant changes, it is still necessary to create new strategies for the implementation of the Ipsas.
\end{abstract}

Keywords: Central American; public sector; government accounting; Ipsas.

DOI: http://dx.doi.org/10.1590/0034-7612131665

(c) (i)

Article submitted on 7 Mar. 2014 and accepted for publication on 11 Aug. 2015.

Acknowledgement: this research was carried out with financial support from the Regional Government of Andalusia (Spain), Department of Innovation, Science and Enterprise (Research Projects P10-SEJ-06628 and P11-SEJ-7700). 
A convergência dos países da América Central para as Normas Internacionais de Contabilidade Nas últimas décadas, os países da América Central estão fazendo esforços significativos para modernizar tanto a legislação do governo sobre a gestão financeira como os dos seus sistemas de informação financeira. Nesse sentido, esses países pretendem aumentar a qualidade da informação financeira pública, a fim de melhorar os processos de tomada de decisão, reduzir o nível de corrupção, e para manter os cidadãos informados. Nesse contexto, o objetivo deste trabalho é duplo. Em primeiro lugar, avaliar o grau de similaridade da informação financeira que está sendo desenvolvido pelos governos da América Central a respeito das recomendações estabelecidas pelas Ipsas e, em segundo lugar, analisar os esforços e estratégias que esses países estão procurando no processo de implementação desses padrões. Para determinar as diferenças informativas contendo as demonstrações financeiras anuais das autoridades públicas nacionais e as recomendações estabelecidas pela Ipsas, realizamos uma análise de conteúdo dedutivo. Em vista dos resultados, podemos dizer que a qualidade das demonstrações financeiras anuais apresentadas pelos países centro-americanos, em comparação com o recomendado pela Ipsas das informações Ifac, não é suficiente, por isso ainda é necessário, para operar mudanças importantes, levantar novas estratégias para implementar as Ipsas.

Palavras-chave: América Central; setor público; contabilidade do governo; Ipsas.

La convergencia de los países de Centroamérica a las Normas Internacionales de Contabilidad En las últimas décadas, los países de Centroamérica están haciendo un significativo esfuerzo para modernizar tanto la legislación gubernamental sobre administración financiera como de sus sistemas de información financiera. En este sentido, estos países pretenden aumentar la calidad de la información financiera pública con el fin de mejorar los procesos de toma de decisiones, reducir el nivel de corrupción, y para mantener a los ciudadanos informados. En este contexto, el objetivo de este trabajo es doble. En primer lugar, para evaluar el grado de similitud de la información financiera que están elaborando por los gobiernos de Centroamérica con respecto a las recomendaciones establecidas por las Ipsas y, en segundo lugar, para analizar los esfuerzos y las estrategias que estos países están llevando a cabo en el proceso de aplicación de estas normas. Para determinar las diferencias informativas que contienen los estados financieros anuales de las administraciones públicas nacionales frente a las recomendaciones fijadas por las Ipsas, llevamos a cabo un análisis deductivo de contenido. A la vista de los resultados obtenidos podemos afirmar que la calidad de los estados financieros anuales presentados por los países de Centroamérica al compararla con la información recomendada por las Ipsas de la Ifac no es suficiente, por lo que es necesario operar todavía cambios importantes, para lo que sería conveniente plantear nuevas estrategias para implementar las Ipsas.

Palabras clave: América Central; sector público; contabilidad pública; NICSP.

\section{Introduction}

Little research has been carried out on questions related to governmental accounting practice in Latin American countries, and less so in those of Central America (Chan, 2003). In the latter region, public financial administration systems have been reformed in a process aimed at 
ensuring that high quality, reliable and timely information is obtained. This would constitute, among other aspects, a good basis for decision taking by users of this information, compliance with the recommendations of financial organisations and of international cooperation agencies, and a factor for improved transparency and accountability.

These reforms have led to the publication of new regulations in the field of public financial administration and the development of programmes to achieve technical and operational advances in financial information systems (Acevedo, 2007). The new legislation establishes, among other aspects, the incorporation of the accrual basis for governmental accounting systems. Moreover, these countries undertake to transmit periodic financial information to international financial organisations, such as the International Monetary Fund (IMF), which publishes the Government Finance Statistics Manual to promote the improvement of governmental accounting information systems. These initiatives, together with the global trend toward convergence with the International Accounting Standards (Ipsas) issued by the International Federation of Accountants (Ifac) (Benito et al., 2007; Alesani et al., 2012), have resulted in a process of increasing approximation to these rules by governmental accounting systems in Central America. Thus, in recent years, most of these countries, to a greater or lesser extent, have taken actions aimed at bringing their governmental accounting systems into line with the Ifac standards for the public sector.

In this regard, the international accounting harmonization through Ipsas aims to sort out the problems of communication, comprehension and analysis of the accounting information in the international environment. As García Benau and partners (1995) points out, the achievement of a financial information equivalent and comparable is got it only via an adequate level of harmonization.

While in the business environment, globalization of markets is probably the main reason to defend the international harmonization of the accounting practices, in the public sector a greater justification is found in the regional globalization that is, in the formation of the economic integrated markets. Governments should harmonize their information to be able to provide a complete image of the financial situation of the common economic framework and, in this way, facilitate the economic decision making process that affect it (Fuertes, 2006).

In this respect, since the last decade it is producing in Latin-America, at the same manner than in the rest of the world, an increment of the interdependence and globalization of the markets, among them the economic regionalization achieved in the Central American countries is also found.

Applying to the Central-American countries the arguments used by Lüder (1992) for the European case, among the reasons for a regional harmonization of the systems of public financial information of the countries that take part, we found:

v Need to buy financial information and changes in the financial position of countries members

v Need to consolidate the financial statements of the countries members in order to have a greater general vision of the financial situation of the group 
v Need to contemplate the same treatment for the concessions and debits of Mercosur in the national accounting systems

In this context, the present study has a twofold objective: on the one hand, to analyse the efforts and strategies implemented by member states of the Central American countries in introducing Ipsas, as proposed by the Ifac; and, on the other, to assess the levels of compliance achieved to date by central governments in Central America with respect to these standards for the presentation of financial information. Therefore, in Section 1 we examine the reforms made in governmental accounting systems, followed in Section 2 by a description of the main actions taken by these countries to adopt or adapt their accounting norms in line with the Ipsas. Section 3 sets out the methodology employed in this comparative study, presents the results obtained and points out some limitations affecting the introduction of the Ipsas. Finally, the main conclusions drawn from this study are highlighted.

\section{Reforms to governmental accounting systems: the situation in Central America}

In recent decades, a series of notable changes have been made in the management policies of governmental organisations, aimed, among other goals, at making public administration an efficient, effective instrument, capable of resolving citizens' problems, overcoming outmoded bureaucratic attitudes and advancing toward a new understanding and philosophy of public management, with particular attention being paid to transparency and accountability (Montesinos and Vela, 1995; Christiaens et al., 2010).

Governmental accounting has become a priority element in this reform process; as observed by the IMF (2001), an adequate accounting system is essential for transparency, accountability and decision taking by public managers. Reforms of governmental accounting systems are aimed at transforming a previously opaque system into one facilitating comprehensive and trustworthy information on public finance, and provide a basis for improving the financial control of governmental activities, to achieve more informative, useful information for decision-taking purposes and accountability (Lüder, 1992).

Governmental accounting has undergone fundamental changes, especially since the 1980s, when various developing countries, including New Zealand, the United Kingdom, the United States, Canada and Australia, undertook the modernisation of their accounting systems. In recent years, this process has also begun in developing countries, and in many cases it has enjoyed the resolute support of international financial organisations (Ouda, 2007).

Among the main factors that have favoured transformations in the area of governmental accounting are the following: the regulatory efforts made at governmental level in various countries (Fuertes, 2006; Dasí, 2013); the proliferation of committees dedicated exclusively to the public sector within professional organisations, at national and international levels (Benito et al., 2007); and the manifest interest shown by the academic sector, which has produced a large body of research and publications on the development of governmental 
accounting in various countries, with respect to both central and local government, as well as comparisons between these countries (Chan, 2003).

In addition, it is generally accepted that the regulatory initiatives undertaken since 2001 by the Ifac, through its Public Sector Committee (PSC), with the economic support of the World Bank, the Asian Development Bank, the UN Development Programme and the IMF, and which have resulted in the publication of the Ipsas, are promoting and producing improved quality and uniformity in financial information throughout the world (Ifac, 2007).

Adoption of the Ipsas by governmental organisations will improve both the quality and the compatibility of financial information provided by public sector bodies, worldwide (Brusca and Montesinos, 2006; Brusca et al., 2013). For this reason, some international organisations, such as the Oecd, Nato and the EU, have already adopted the Ipsas (Benito et al., 2007), while others, such as the IMF, the World Bank and the Inter-American Development Bank (BID), have urged different governments (especially those of developing countries, to adopt or adapt these standards (Chang et al., 2008).

As indicated by ICGFM (2014), the work plan for the implementation of Ipsas is not a universal recipe, as each country is different and the national authorities should establish the objectives that can be achieved and the time that it will be needed. Thus, this body indicates that in a first phase, a reference must be included in the national legislation that indicates the requirement of NICSP adoption; establishment of a directive committee for the approval of the objectives and action plan for NICSP implementation; performing an analysis of the deficiencies of the current financial statements; developing a realistic calendar of implementation, ensuring the accomplishment of the terms; informing to the university teachers of accounting about the new accounting systems in order to train its students; revising the accounting agreements and the existing reports of exterior aid, etc.

In the particular case of the countries in Central America, the high levels of debt and budget deficits arising from the economic crises of the 1980s led these governments to embark on a process of structural adjustment, with the aim of controlling public expenditure, together with a process of re-insertion into the world economy by means of greater economic openness (Large, 2005). In addition, international financial organisations promoted a series of structural reforms and economic adjustments aimed at modernising public financial administration to make it more efficient, effective and transparent (World Bank, 2000). In this context, a series of State modernisation programmes began to appear in Central America, including reforms of financial administration, and a renovation of the operational aspect of public finances.

Nevertheless, dramatic advances in financial administration reforms in Central America did not take place until the early 1990s, with the combined effect of various factors, but especially that of the rigorous position taken by financial organisations and donors. These bodies insisted that a fundamental requirement for greater international cooperation with the countries of Central America was that adequate use be made of the financial resources assigned to them (Maldonado and Berthin, 2004). 
The reform process got under way with the implementation of the Integrated Financial Management System (Siafpa) in Panama in 1992, and its first stage concluded in 2005 with the entry into force of the Financial Management and Budgetary System Law, No. 550, in Nicaragua (see table 1).

Table 1

Financial management reforms and legislation in Central America

\begin{tabular}{|llc|}
\hline Country & Legislation & Passed in \\
\hline Costa Rica & Financial Management and Public Budget Law, No. 8131 & 2001 \\
El Salvador & National Financial Management Organic Law, No. 516 & 1995 \\
Honduras & Organic Budget Law, No. 83-2004 & 2004 \\
Guatemala & Organic Budget Law, No. 101-97 & 1997 \\
Nicaragua & Financial Management and Budgetary System Law, No. 550 & 2005 \\
Panama & Annual National Budget Law and International Standards of Government Accounting & 1997 \\
\hline
\end{tabular}

Source: The authors, based on the laws published by each country.

With respect to public sector accounting, it can be seen that, in general, under the new legislation passed in these countries, the subsystem of governmental accounting is comprised of a body of principles, norms and technical procedures for the systematic compilation, registration, processing and control of all information obtained concerning financial operations in the public sector. One of the main innovations made to governmental accounting systems is the introduction of accrual as the basis for recording economic transactions (although, at the present date, this accounting principle is not yet being fully applied in any of the countries studied).

During the last years, various factors have led all the countries in the region except Nicaragua to undertake actions aimed at bringing their accounting systems into line with Ifac rules for the public sector. Among others, the initiatives present the following aspects of interest:

v The process by which the International Financial Reporting Standards (IFRS) of the International Accounting Standards Board (Iasb) are being adopted as norms regulating private sector accounting in all countries in the region. This move to introduce internationally applicable standards into the governmental sector has aroused considerable interest among public managers.

v The interest expressed by audit bodies in enforcing the legislation passed with respect to governmental accounting systems.

v The conviction among staff in governmental accounting organisations, in each of the countries concerned, of the need to modernise accounting systems. 


\section{Main actions taken by Central American countries to adapt or adopt the Ipsas}

In El Salvador, in 2005, the Regulatory Department of the Directorate General for Governmental Accounting (DGCG) began a process to analyse the possible implications and benefits of adopting or adapting the Ipsas in the context of El Salvador. On the basis of the results obtained from this study, an action plan was drawn up to standardise the existing governmental accounting system with the recommendations made in the Ipsas. This action plan consisted of six phases: diagnosis, design, development, testing, implementation and evaluation, and human resources skills training.

As part of the actions taken in the first and second phases, legislation was proposed to regulate the system of governmental accounting in accordance with the Ipsas recommendations. Similarly, the proposal was made for a new conceptual framework for the system of governmental accounting, and a new protocol for the processing and cataloguing of public sector accounts was prepared, also in accordance with the Ipsas. According to the information supplied by the Director of the DGCG, from 2014, the rules and procedures regulating governmental accounting will be adapted to the content of the public sector accounting regulations published by the Ifac.

In Guatemala, also in 2005, with the support of a group of international consultants and that of the Guatemala Institute of Public Accountants and Auditors, an analysis was made of the system of governmental accounting. This led to the decision by the State Accounting Directorate (DCE) to issue its own accounting rules, but in convergence with the Ipsas. Thus, in late 2006, the first version of the Accounting Rules for the Public Sector in Guatemala was published.

In 2011 the Steering Committee of Ipsas was formed. This Committee has developed a "review sheet" for the implementation of Ipsas which defines, amongst others, a training and analysis programme on diverse norms. These norms have been compared with the current mandatory norms from Guatemala. In this process, the implementation plan of the Ipsas number 1, 2, 9, 17 and on a Cash Basis have been approved.

At the date of development of such document, a ministerial or governmental agreement has not been issued in order to legally support Ipsas adoption. However, the Steering Committee states that, from January 1, 2014 the international norms should be adopted in the public sector and on a Cash basis. Likewise, they should be also implemented on an accrual basis from January 1, 2017.

Meanwhile, in Honduras, in 2006, the Comptroller-General of the Republic (CGRH) issued a Ministerial Decree of Technical Standards for the Governmental Accountability Subsystem, in which it was stated that the rules and accounting procedures in the public sector "should be in accordance with the Accounting Standards for the Public Sector...".

Based on the Resolution No. 269 of February 8, 2012, the Secretary of State in the Office of Institutional Finance Committee created the Institutional Committee of Ipsas Adoption. Subsequently, in November 2012 the Internal Regulation of the Institutional Committee of Ipsas Adoption were approved. Amongst the functions assigned to the Committee, it should 
be highlighted, on the one hand the establishment of a roadmap for Ipsas implementation and on the other hand, its contribution for a greater dissemination and training related to Ipsas in the governmental institutions.

In this respect, the Committee made a review sheet and an implementation plan of Ipsas in Honduras. Both documents, present a calendar indicating the actions, related to the training, study and analysis of the Ifac international norms, are going to be performed. In particular, by April 30, 2015 a general proposed of consolidated financial statements have been developed based on the Ipsas. In this context, there is an expectation to initiate by 2016 the mandatory issuance of financial statement regarding Ipsas.

In Panama, during 2007 and 2008, the Directorate for Accounting Methods and Systems (DMSC) began a process to review and adapt governmental accounting standards, and carried out an initial comparative analysis of these norms and those stated in the Ipsas.

In 2012, the Comptroller General through the DMSC initiated the Plan for Accounting System Modernization. To this end, a consulting service was contracted and through it the Phase I and II were finished in 2012. With respect to phase I, the development of a new General Governmental Accounting Manual was carried out. Regarding Phase II, twelve Technical Guides of Governmental Accounting were performed. These were orientated to the international accounting norm for the public sector and according to the Manual on Statistics of International Monetary Fund 2001.

For the stage III and IV, in 2013, the references terms were drawn up in order to contract a consulting service that develops the Strategic Plan for both, the implementation process of Ipsas and to complement the Draft General Accounting Manual.

In Costa Rica, in 2008 the Directorate General for National Accounting (DGCN) proposed the adoption of the Ipsas issued by the Ifac. To this effect, a series of executive decrees were drafted, concluding with the approval of Decree No. 34918-H of 9 December 2008, by which approval was granted to the "Adoption and Implementation of International Accounting Standards for the Public Sector in Costa Rica" from January 1, 2012. However, due to the inability to meet that deadline, in February 2012 a new decree (No. 36961-H) has been issued. In this new decree the deadline for the implementation of Ipsas is extended by January $1,2016$.

In order to advance the implementation of the new regulations, the government of Costa Rica, with financial support from the Costa Rica-USA Foundation (Crusa), hired an international consulting firm to design the General Plan for Public Accounts adapted to Ipsas. In this regard and according to Directive $\mathrm{CN}-01-2012$ public entities, until the final implementation in 2016, must submit quarterly progress reports following the form provided by the National Accounts. These reports aim to collect data to evaluate the institution progress concerning the most relevant topics, collaborate with troubleshooting and, perform statistical analysis by institutional groups.

Other important actions that have been taken include: specific skills-building programmes; hiring a project leader; informing the public of the progress made in the General Plan for 
Public Accounts and inviting observations and suggestions; providing e-mail and telephone facilities for inquiries from public sector employees in this field; www.nicspcr.com was enabled site; the monthly publication of an information bulletin detailing the main actions taken, together with general information concerning the Ipsas; and the development and approval of an Action Plan to implement the Ipsas, setting out the strategies to be developed in order to effectively comply with the decrees issued.

Finally, in Nicaragua, to date no specific actions have been taken to harmonise national law and practice in governmental accounting with the Ipsas. Nevertheless, the head of the Directorate General for National Governmental Accounting (DGCGN), in a personal interview with the authors, observed that in the near future a strategy in this respect will be defined. There are various indications that Nicaragua will implement a process similar to that followed by the other countries in the region in the field of governmental accounting. This process will foreseeably include the following: the adoption of the IFRS as the regulatory framework for accounting in the private sector in Nicaragua; the trend towards standardising rules with neighbouring countries, within the Central American framework; compliance with the demands for greater transparency made by financial organisations and by international cooperation agencies; and convergence with the international trend favouring the adoption or adaptation of the Ipsas.

Chart 1 summarises the main actions taken by countries in Central America to adopt or adapt the Ipsas.

Chart 1

Main actions taken in processes of Ipsas adoption-adaptation

\begin{tabular}{|c|c|}
\hline Country & Main actions taken \\
\hline Costa Rica & $\begin{array}{l}\text { Decree No. 34918-H, of December 2008, approved the adoption of Ipsas in Costa Rica. Decree No. } \\
36961-\mathrm{H} \text {, of February 2012, by which the effective date of Ipsas by January 1, } 2016 \text { is amended. }\end{array}$ \\
\hline El Salvador & $\begin{array}{l}\text { Currently adopting its regulations to those stipulated in Ipsas. An action plan has been prepared, } \\
\text { according to which implementation is scheduled to begin in } 2014 \text {. }\end{array}$ \\
\hline Guatemala & $\begin{array}{l}\text { In } 2011 \text { the Ipsas Steering Committee was formed. This Committee suggests that, from January 1, } \\
2014 \text { the Ipsas should be adopted on a cash basis and, from January 1, } 2017 \text { on an accrual basis. }\end{array}$ \\
\hline Honduras & $\begin{array}{l}\text { By resolution No. } 269 \text { of February 8, 2012, the Institutional Committee of Ipsas Adoption is created. By } \\
\text { April 30, 2015, it is expected a general proposed of consolidated financial statements based on Ipsas. }\end{array}$ \\
\hline Nicaragua & No actions taken in this respect. \\
\hline Panama & $\begin{array}{l}\text { In 2012, twelve Technical Guidelines of Governmental Accounting were developed. These guidelines } \\
\text { were oriented on Ipsas implementation. In September 2013, the hiring of a consultant to develop the } \\
\text { strategic plan implementation is in process. }\end{array}$ \\
\hline
\end{tabular}

Source: The authors. 


\section{Convergence of governmental financial information in Central American countries with the Ipsas of the Ifac}

The countries considered in this study are all members of the Central American Integration System (Sica), whose aims include achieving an economic union. They all need comparable financial data, and for this purpose the use of common accounting standards is highly desirable. Therefore, the application of Ipsas in this region could open the way to the modernization of public accounting systems and enhance the preparation and comparability of national accounts (Benito et al., 2007).

To determine differences in the information that contains the annual financial statements and the international Ipsas we conducted a content analysis. The type of content analysis implemented is deductive as we have codified the information into pre-defined financial statement and items derived from the literature reviewed according to Berg (2001).

Thus, in order to verify the extent to which the information requirements of Ipsas 1 and 2 have been achieved to date by the central governments of Central American countries, according to Torres (2004) and Caba and López (2007), we created an index, setting out the minimum requirements applicable to annual financial statements. For this purpose, two levels were considered.

Level 1. This level distinguishes countries in terms of their presentation of the different financial statements which, according to Ipsas 1, must be presented at year end, irrespective of their content. This first level refers to the five components that constitute annual financial statements, namely: Statement of Financial Position, Statement of Comprehensive Income, Statement of Cash Flows, Statement of Changes in Equity and Notes to the Financial Statements.

Level 2. This level focuses on the content to be published in each of the above financial statements, distinguishing 76 aspects that should be considered in annual financial statements, as detailed in annex 1 .

The total number of requirements for financial statements presented by central government in compliance with Ipsas provisions is obtained by summing the score for each of the areas shown in annex 1, that is, a total of 76 items for the five components making up the basic financial statements.

To determine the score awarded to each country, a dichotomous procedure is used in which one point is awarded if the item is included in accordance with Ipsas stipulations and zero points otherwise. When all the items have been verified, an index is constituted to measure the total level of compliance with the minimum requirements stipulated for central government financial statements in each country, as established in the Ipsas (CT) and an identical evaluation is made for each of the components of the financial statements, that is, an evaluation of $20 \%$ for each of the five basic statements. The partial weighting for each financial statement is obtained by dividing the total score obtained $(C P)$ by the maximum number of items that can be achieved (m), i.e., $\mathrm{CPb}=\mathrm{Po} / \mathrm{m}^{*} 100$ for the Statement of Financial Position, $C P r=P o / m * 100$ for the Statement of Comprehensive Income, $\mathrm{CPf}=P \mathrm{O} / \mathrm{m} * 100$ 
for the Statement of Cash Flows, $C P p=P o / m * 100$ for the Statement of Changes in Equity and $C P n=P o / m * 100$, for the Notes to the Financial Statements.

Therefore, to generate the total level of compliance in Level 2 (CT), we sum the partial results obtained for each component and divide this value by the total number of components of the financial statements, as follows:

$$
C T=C P b+C P r+C P f+C P p+C P n / 5
$$

For each of the items in Level 1, we obtain a partial index of compliance, defined as follows: CTb for the Statement of Financial Position, CTr for the Statement of Comprehensive Income, CTf for the Statement of Cash Flows, CTp for the Statement of Changes in Equity and CTn for the Notes to the Financial Statements.

The analysis of the content of each financial statement selected was hand coded by two coders that worked independently using a pre-defined scheme. This data collection method presents a low potential of inter-rater coding errors as the coding scheme does not present many sub-dimensions and there is no independency and interactivity among the items used (Milne and Adler, 1999).

\section{Results of the implementation of Ipsas 1 and 2}

Before detailing the results of this study, it should be noted that despite much effort and many contacts with the authorities of the ministry of Finance and Public Credit of the Republic of Nicaragua, at the present date, we have been unable to obtain the consolidated financial statements from the central government of this country.

In the present study, we analysed the information provided in the consolidated financial statements for the public sector for each of the countries in question for the year 2012. To complement this information, during September and October 2013, we held personal interviews with the directors general of Accounting and representatives of the Comptroller General in each of the same countries.

As shown in Graphic 1, the only Central American country that fulfils all five components that make up the annual financial statement, in accordance with the provisions of Ipsas 1 , is Costa Rica. This is a noteworthy result; although this country was the last to begin the process of adaptation to the Ipsas, to date it has made most progress in this field. On the contrary, the countries which took the first steps to introduce the Ipsas, namely El Salvador, Guatemala and Nicaragua, have achieved the poorest results, with a convergence of only $60 \%$. In the case of Panama, although the process of introducing the Ipsas has not yet begun (it is currently diagnosing the situation of its accounting models in this respect), at present its information preparation practices are reasonably close to the recommendations of Ipsas 1 , with four of the five financial statements cited being published. 
Similarly, Graphic 1 shows that of the annual financial statements required by the Ipsas, those most often provided are the Statement of Financial Position and the Statement of Comprehensive Income, which are presented by the five countries analysed. On the other hand, the Statement of Cash Flows and the Statement of Changes in Equity are provided by only two countries. These results contrast to the contents obtained in countries from the same environment such as those from Mercosur (Caba and López, 2007), as Argentina, country that present the greatest grade of accomplishment with the Ipsas had, only developed 4 of these 5 financial statements, while other countries like Uruguay did not developed none of them.

\section{Graphic 1}

First level degree of compliance with the Ipsas proposed by Ifac

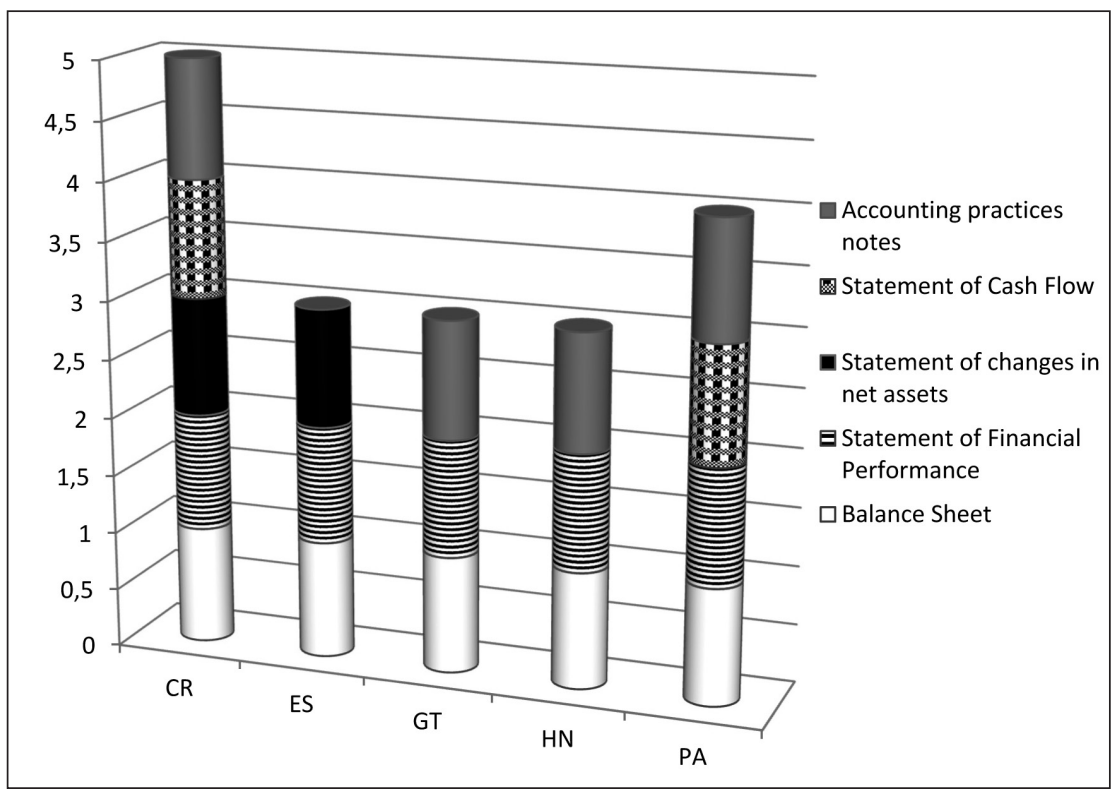

Source: Own production.

On the basis of the information detailed in the previous section, we analysed the fulfilment of Level 2, making a closer analysis of the content that should be published in each of the financial statements, as summarised in Graphic 2.

Our analysis of the items making up the financial statements shows that, for the preparation of the Statement of Financial Position (see Graphic 2), the information presented by each of the countries presents a very high level of compliance with the requirements of Ipsas 1. The case of Costa Rica is outstanding; this country's Statement presents all of the items recommended, and therefore it has totally introduced the informational requirements of Ipsas 1. The cases of Guatemala, Honduras and El Salvador also present a very high level of compliance, with $94 \%$ in the first two cases and $82 \%$ in the third. In the case of the Mercosur 
countries (Caba and López, 2007), Argentina was the country that reached the greatest grade with a $88,3 \%$ of compliance, but still was far from countries like Costa Rica.

Graphic 2

Second level degree of compliance with the Ipsas proposed by Ifac

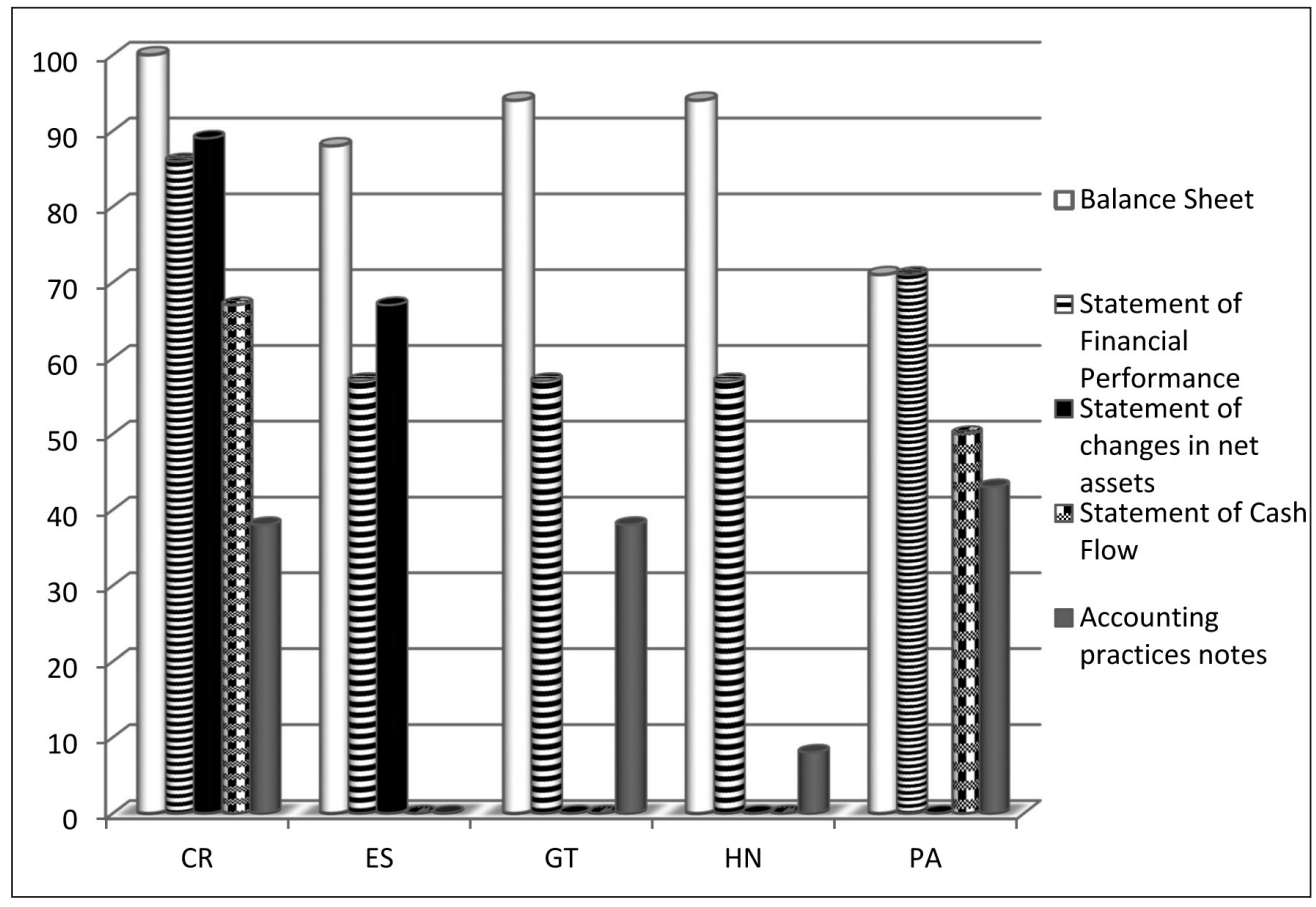

Source: Own production.

With respect to the components of the Income Statement, the level of compliance with Ipsas recommendations is reasonably satisfactory. The countries with the highest indexes in this respect are Costa Rica and Panama, with 86\% and 71\%, respectively. Honduras, Guatemala and El Salvador provide $57 \%$ of the elements constituting this section of the financial statement, very similar data to countries with the greatest compliance in Mercosur like Argentina and Paraguay. It is striking that only Costa Rica includes the surplus or deficit of ordinary activities in its Income Statement. Moreover, only Panama details the extraordinary items in its Income Statement. These aspects indicate that it is necessary to continue working to adapt this financial statement to fully comply with Ipsas 1 .

As remarked above, the cash flow statement is only presented by Costa Rica and El Salvador. Costa Rica complies with $89 \%$ of the Ipsas 2 stipulations, and El Salvador, with $67 \%$, situation that contrasts to Brasil and Paraguay, nevertheless although both are the only countries that develop it, they only accomplish $11,1 \%$ and 55,5\%, respectively. In neither case are cash flows associated with extraordinary items described separately. 
As observed in our analysis of Level 1, an equity change statement is only presented by Costa Rica and Panama, which currently apply $67 \%$ and 50\%, respectively, of the recommendations set out in Ipsas 1. Likewise, in Mercosur countries, only Argentina was present with a similar compliance to the rest of the countries (Caba and López, 2007).

According to the Ipsas, the notes to the financial statements form an integral part of the set of financial statements. Of the countries analysed, only El Salvador fails to include this information. However, the other countries analysed achieve very low levels of compliance with the Ipsas recommendations, with Costa Rica and Guatemala recording 38\%, while the best performance in this respect is that of Panama, with only $43 \%$.

In general, the presentation of the notes is the item that is least well applied in the preparation of financial statements, quite similar situation to Mercosur environment (Caba and López, 2007). Within the subdivisions of this area, the category that is most poorly applied concerns the data supporting the general information in the financial statements, that is, the long-term data constituting the reference framework on the basis of which users of financial statements may comprehend the context and the principal accounting policies on which the financial information detailed in the annual statements is grounded. With respect to the notes concerning the overall statement of financial position, little importance seems to be granted to aspects such as leasing, construction contracts, recognition, the depreciation and deterioration of tangible and intangible assets, provisions and contingent debt or contractual obligations.

In summary, in the financial statements published by countries in the Central American region for 2012, a low level of compliance is achieved with the requirements set out in Ipsas 1 and 2, with this situation being slightly similar to the existing in Mercosur environment. Thus, Costa Rica, which to date has achieved the greatest convergence, scarcely attains $75 \%$ compliance, while the other countries do not even reach 50\%. As observed above, the presentation of the notes to financial statements is the section presenting the lowest degree of convergence (see Graphic 3).

Graphic 3

Rating the overall level of compliance with Ipsas

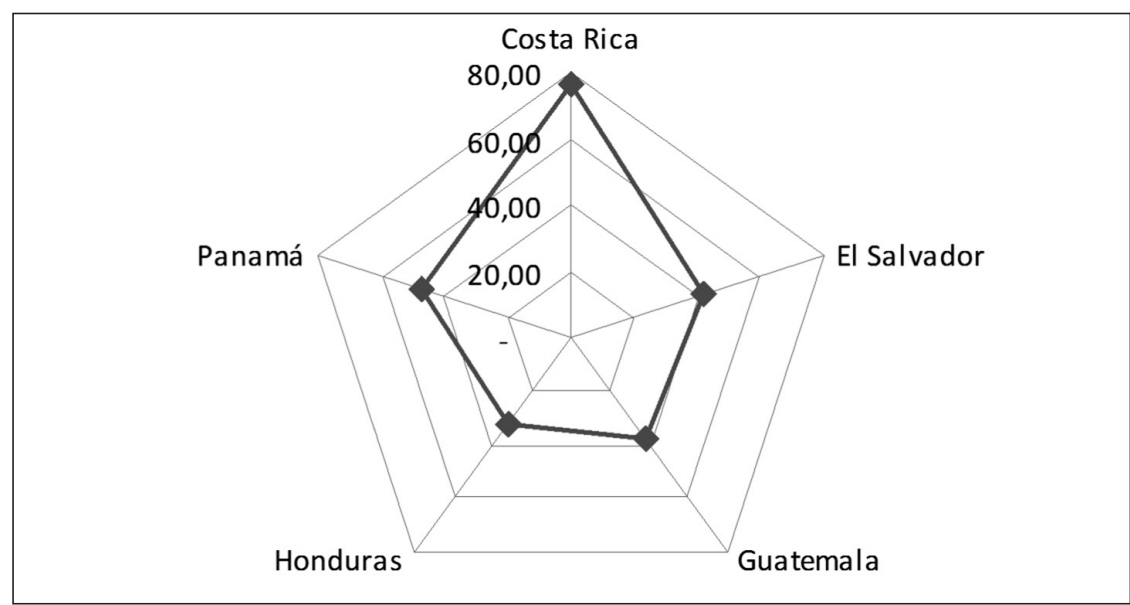

Source: Own production 


\section{Limitations to the Ipsas implementation strategies}

With respect to the implementation strategies followed in the different countries in adopting or adapting their systems to the Ipsas, it should be noted that with the exception of Costa Rica and Guatemala, in all these countries the process is taking place under the exclusive control and management of the accounting regulatory body. In other words, in most cases the processes taking place are highly centralised, and this, as observed by authors such as Lüder (1992) and Ouda (2007), does not favour the introduction of innovations into governmental accounting systems. Similarly, there has been little participation in these processes by representatives from the academic sector, professional colleges or organisations, or external audit firms. Bearing in mind the important role played by these actors in similar processes in other geographic areas, and the fact that diverse authorities consider such participation fundamental to the success of the process, we believe the participation of these agents should be encouraged.

Furthermore, none of the countries in question has adequately estimated the costs associated with the process of implementation, and has not allocated specific resources for this purpose, a shortcoming that is bound to hamper achievement of the goals proposed. Similarly, with the exception of El Salvador, no country has studied the technological requirements involved and the adaptations to computing systems that will need to be carried out.

The existence of action plans for introducing Ipsas in most countries is evidence of the interest among different governments in initiating processes of innovation within their national accounting systems. Nevertheless, in the cases of El Salvador and Guatemala these processes have advanced at a very unhurried rate. Indeed, in the case of Guatemala, at the present date, no additional action has been taken since 2006 and it remains to be seen whether the political promoters of these reforms will reinitiate their progress. These considerations lead us to assume that these promoters do not enjoy the unreserved support of Ministry of Finance authorities to develop the adoption and implementation of Ipsas in all its phases and aspects.

\section{Conclusions}

In recent years it is producing a clear convergence in the presentation of certain budgetary information in these countries, the truth is that still continuing existing divergences regarding the financial information.

Thus, the regional area of Central America can give an impulse to the harmonization of the systems of public accounting information, therefore it should be necessary to consider the norm that should be established to reach that harmonization. Until very recent dates, the absence of international norms of accounting for the public sector has been the predominant note. However, in the last years the efforts have been intensified in order to change this panorama. In fact, the International Federation of Accountants (Ifac), via it's Committee for the Public Sector (CSP), is carrying out the adoption of international accounting norms for public sector. Hence Ifac for the moment is one of the main bodies that have shown its interest in this field. 
Thus, over the last 15 years, the countries of Central America have made significant efforts to modernise governmental financial information systems, both from the operational standpoint and from that of legal reforms. This process has enabled these countries to present in their annual reports both budgetary information and financial information, thus affording greater utility, transparency, comparability and accountability, and enhancing decision-taking processes in public management.

The countries in this region, to a greater or lesser extent, have taken action to bring their accounting systems into convergence with Ifac standards for the public sector. They have done so for various reasons, including the need to harmonise national financial information with the requirements of international financial organisations, the conviction among the authorities of governmental accounting bodies of the need to modernise their accounting systems, and the worldwide trend favouring the adoption or adaptation of Ipsas.

From our comparison of the Ipsas and the detailed information presented in these countries' financial statements, we conclude that the main concern of governmental authorities is to present the statements of financial position and of income. On the contrary, non-financial information, such as performance indicators, receives scant attention and publication.

In general, the annual financial statements presented by the countries of Central America, although advancing toward the Ipsas recommendations, have not yet reached a very high degree of convergence with this international standard. Much remains to be improved, especially regarding the information that should be included in the notes to the financial statements, with this situation being slightly better than in the case of the countries from Mercosur. Therefore, important changes should be applied, affecting not only the statements and the notes as such, but also their content.

Costa Rica is currently the leading country in Central America in moving to introduce Ipsas and innovate its governmental accounting systems. The decree to this effect has already been approved, a detailed action plan has been developed, specific skills training actions have been put in place, an international consulting firm has been hired to develop the new General Plan for Public Accounting, and the complete implementation of Ipsas in the public sector is scheduled to begin on 1 January 2016. These advances, from the regulatory standpoint and that of the practical implementation of innovations in its accounting systems, are reflected in the greater level of convergence of its financial statements with the content of Ipsas 1 and 2.

\section{References}

ACEVEDO, Carlos. Gasto público social y procesos presupuestarios en Centroamérica. Guatemala: Instituto Centroamericano de Estudios Fiscales (Icef), 2007. Available at: < http://unpan1.un.org/ intradoc/groups/public/documents/ICAP/UNPAN028014.pdf>. Access on: 24 ${ }^{\text {th }}$ Feb. 2009.

ALESANI, Daniele; JENSEN, Gwenda; STECCOLINI, Ileana. Ipsas adoption by the World Food Programme: an application of the contingency model to intergovernmental organisations. International Journal of Public Sector Performance Management, v. 2, n. 1, p. 61-80, Aug. 2012. 
BENITO, Bernardino; BRUSCA, Isabel; MONTESINOS, Vicente. The harmonization of government financial information systems: the role of the Ipsass. International Review of Administrative Sciences, v. 73, n. 2, p. 293-317, 2007.

BERG, Bruce L. Qualitative research methods for the social sciences. Boston: Allyn and Bacon, 2001. BROADBENT, Jane; GUTHRIE, James. Public sector to public service: 20 years of contextual accounting research. Accounting, Auditing \& Accountability Journal, v. 21, n. 2, p. 129-180, 2008.

BRUSCA, Isabel; MONTESINOS, Vicente. La armonización de la contabilidad pública en el contexto internacional. In: IX JORNADA DE CONTABILIDAD PÚBLICA ASEPUC, 2006, Logroño, Spain.

BRUSCA, Isabel; MONTESINOS, Vicente; CHOW, Danny S. L. Legitimating International Public Sector Accounting Standards (Ipsas): the case of Spain. Public Money \& Management, v. 33, n. 6, p. 437-444, Nov. 2013.

CABA PÉREZ, Carmen; LÓPEZ-HERNÁNDEZ, Antonio Manuel. Governmental financial transparency in Mercosur member countries. International Review of Administrative Sciences, v. 75, n. 1, p. 169-181, 2009.

CABA PÉREZ, Carmen; LÓPEZ-HERNÁNDEZ, Antonio Manuel. Latin-American public financial reporting: recent and future development. Public Administration and Development, v. 27, n. 2, p. 139-157, 2007.

CHAN, James. Government accounting: an assessment of theory, purposes and standards. Public Money \& Management, v. 23, n.1, p. 13-20, 2003.

CHANG, C. Janie; CHEN, Gongmeng; CHOW, Chee W. Exploring the desirability and feasibility of reforming China's governmental accounting system. Journal Public Budgeting, Accounting \& Financial Management, v. 20, n. 4, p. 482-510, 2008.

CHRISTENSEN, Mark; YOSHIMI, Hiroshi. Public sector performance reporting: new public management and contingency theory insights. Government Auditing Review, v. 10, n. 3, p. 71-83, 2003.

CHRISTIAENS, Johan; REYNIERS, Brecht; ROLLÉ, Caroline. Impact of Ipsas on reforming governmental financial information systems: a comparative study. International Review of Administrative Sciences, v. 76, n. 3, p. 537-554, 2010.

DASÍ, Rosa Ma.; MONTESINOS, Vicente; MURGUI, Santiago. Comparative analysis of governmental accounting diversity in the European Union. Journal of Comparative Policy Analysis: Research and Practice, v. 15, n. 3, p. 255-273, 2013.

FUERTES, Iluminada. El modelo de contabilidad pública internacional de la Ifac: análisis de la armonización formal. In: IX JORNADA DE CONTABILIDAD PÚBLICA ASEPUC, 2006, Logroño, Spain.

GARCÍA BENAU, María Antonia; LAÍNEZ, José; MONTERREY, José. La investigación en contabilidad internacional: una visión panorámica. Revista Española de Financiación y contabilidad, v. 24, n. 83, p. 337-363, 1995.

ICGFM. Plan de trabajo para la implementación de la guía de compilación para países en vías de desarrollo. 2014. Available at: <www.icgfm.org/conferenceDocs/2014/Dec/IPSASB_PANEL_Ron- 
Salole_SP.pdf $>$. Access on: $9^{\text {th }}$ June 2015.

INTERNATIONAL FEDERATION OF ACCOUNTANTS. Manual de pronunciamientos de la Junta de Normas Internacionales de Contabilidad del Sector Público. New York: Ifac, 2007.

INTERNATIONAL MONETARY FUND (FMI). Government finance statistics manual 2001. Statistics Department. Washington, DC: FMI, 2001.

LARGE, William R. Una sólida alianza para el desarrollo: Centroamérica y el BID desde 1990. Washington, DC: Banco Interamericano de Desarrollo, 2005.

LÜDER, Klaus. A contingency model of governmental accounting innovations, in the political-administrative environment. In: CHAN, James; JONES, Rowan (Ed.). Research in governmental and nonprofit accounting. Greenwich, CT: JAI Press, 1992. v. 7, p. 99-127.

MALDONADO, Patricio; BERTHIN, Gerardo D. Transparency and developing legal frameworks to combat corruption in Latin American. Southwestern Journal of Law and Trade in the Americas, v. 10, n. 2, p. 101-118, 2004.

MILNE, Markus J.; ADLER, Ralph W. Exploring the reliability of social and environmental disclosures content analysis. Accounting, Auditing \& Accountability Journal, v. 12, n. 2, p. 237-256, 1999.

MONTESINOS, Vicente; VELA, Jose Manuel. International research in public sector accounting, reporting and auditing. Valence: Instituto Valenciano de Investigaciones Económicas, 1995.

OUDA, Hassan. Accrual accounting in the government sector, background, concepts, benefits and costs. The International Consortium on Governmental Financial Management, v. 6, n. 1, p. 39-52, 2007.

SALEH, Zakiah. Malaysian governmental accounting: national context and user orientation. International Review of Business Research Papers, v. 3, n. 2, p. 376-384, 2007.

TORRES, Lourdes. Accounting and accountability: recent developments in government financial information systems. Public Administration and Development, v. 24, n. 5, p. 447-456, 2004.

WORD BANK. Reforming public institutions and strengthening governance: a Word Bank strategy. Washington, DC: World Bank, 2000.

Carlos Araya-Leandro is vice-rector at the University of Costa Rica. E-mail: carlos.arayaleandro@ucr.ac.cr. María Del Carmen Caba-Pérez is associate professor at the University of Almería. E-mail: ccaba@ual.es. Antonio M. López-Hernandez is professor at the University of Granada. E-mail: alopezh@ugr.es. 


\section{Annex 1}

\section{Issues to consider the financial statements under Ipsas 1 and 2}

1. BALANCE SHEET ITEMS: 1.1. Non-financial fixed assets; 1.2.Tangible assets; 1.3.Intangible assets; 1.4.Investments; 1.5. Short and long-term financial assets disclosed separately; 1.6. Receivables; 1.7. Short and long-term receivables disclosed separately; 1.8. Cash and cash equivalents; 1.9. Prepayments; 1.10. Payables; 1.1 1.Short and long-term payables disclosed separately; 1.12. Borrowing; 1.13. Short and long-term borrowings disclosed separately; 1.14. Current portion of borrowing disclosed separately; 1.15. Provisions; 1.16. Net asset/equity; 1.17. Current and non-current assets and current and non-current liabilities as a separate classification or in order of liquidity.

2. OPERATING STATEMENT ITEMS: 2.1. Revenue from operating activities; 2.2. Surplus or deficit from operating activities; 2.3 . Finance costs; 2.4 . Surplus or deficit from ordinary activities; 2.5 . Extraordinary items; 2.6. Net surplus or deficit for the period; 2.7. Expenses are aggregated according to their nature, programme or purpose.

3. CASH FLOW ITEMS: 3.1. Net use of cash payments arising from operating activities disclosed separately; 3.2. Major classes of gross cash receipts and gross from operating activities disclosed separately; 3.3. Use of net cash payments arising from investing activities disclosed separately; 3.4. Major classes of gross cash receipts and gross from investing activities disclosed separately; 3.5. Net use of cash payments arising from financing activities disclosed separately; 3.6. Major classes of gross cash receipts and gross from financing activities disclosed separately; 3.7. Cash flows associated with extraordinary items disclosed separately; 3.8. Cash flows associated with interest received and paid as either operating, investing or financing activities disclosed separately; 3.9. Reconciliation of the amounts in the cash flow statement with the equivalent items reported in the statement of financial position disclosed.

4. CHANGES IN NET ASSETS: 4.1. Net surplus or deficit for the period; 4.2. Each item of revenue and expense, recognized directly in net asset/equity, and total of these items; 4.3. Contributions by owners and distribution to owners, in their capacity as owners; 4.4. Cumulative effect of changes in accounting policy and the correction of fundamental errors; 4.5. The balance of accumulated surpluses or deficits at the beginning of the period and at the reporting date, and movements for the period; 4.6. A reconciliation between the earning amount of each component of net asset/equity at the beginning and end of the period.

5. NOTES TO THE FINANCIAL STATEMENTS

5.1Balance sheet backup information

5.2Operating account backup information.

5.3General financial balance sheet backup information.

Source: Caba and López (2007). 